the "plural" society. Though one may disagree with some of the distinctions he draws between class conflict on the one hand and racial or ethnic conflict in plural societies on the other, his paper greatly illuminates the whole question of racial versus class consciousness and conflict.

Among the empirical contributions, that by Sheila Allen provides a good example of the integration of research in race relations with that in industrial sociology. She shows that the failure of the trade unions in Bradford to involve the lower skilled workers quickly became transformed into a racially defined conflict when the workers concerned were immigrants.

This book indicates that future research will move into more politically relevant areas-as social and economic structures become the objects of analysis. It also promises a more theoretical orientation in a field previously dominated by the British empiricist tradition. This book can be recommended to all who welcome such developments.

JeNnifer HuRstfield

\section{CARE OF SCHIZOPHRENICS}

\section{Institutionalism and Schizophrenia}

A Comparative Study of Three Mental Hospitals 1960 1968. By J. K. Wing and G. W. Brown. Pp. xiii +260. (Cambridgo University: London, September 1970.) $75 s$.

THE authors of this book set out to evaluate the effects of the changing social milieu on hospitalized fomale schizophrenics. They describe their attompt as a search for "hard and obstinate facts" rather than for novel theories, and they have been succossful. It is clear, as the authors point out, that all the polemic and propaganda for changes in hospital regimes and the real improvements that have occurred have been necessary from the point of view of humanity alone; but it is also pertinent to ask whether these changes have also resulted in the reduction of illness handicaps and in the encourage. ment of personal improvement. Their chapter on this area is a useful review of previous work.

Methodologically, the investigation rosts on the firm basis of techniques tho reliability and validity of which have been tested in earlier research. Assessments are made of the clinical condition of the patients and of the ward environments in which they live in three British hospitals. An attempt is made to show that certain "negative" aspects of the clinical condition, such as social withdrawal, are associated with the poverty of the social situation in which the patient finds horself. This hypothesis and numerous subsidiary ones are supported by a "crosssectional" analysis of the patients and conditions in the three institutions. Advantage has then been taken of changes which occurred in the organization of their treatment regimes, during periods of four and eight years, to illuminate the problems of cause and effect in the associations established. Useful evidence, pointing to the efficacy of a richer social environment in evoking more positive behaviour, has certainly been forthcoming.

The work is liberally illustrated with clinical anecdotes and descriptive chapters on the wards studied. This produces a somewhat uneven texture in the book which is offset by the gains in understanding of the institutions and personalities concerned.

This is an essential text for anybody involved in the management of institutional care of patients. It gives a balanced view of the interaction between possible biological and social factors in the evolution of this particular condition but, more than this, it indicates the possibilities of stepping into natural experimental situations, and, with quite simple methods and analysis, achieving a rational assessment of the effectiveness of treatment ideologies.

J. A. Clarke

\section{BUTTERFLY BEAUTIES}

A Field Guide to the Butterflies of Britain and Europe By Lionel G. Higgins and Norman D. Riley. Pp. $380+60$. (Collins: London, September 1970.) 42s.

AMateur and professional entomologists alike will welcome this book for its authority, its thoroughness and at the same time its simplicity which enables even the beginner to identify rapidly the "rare" butterfly which he finds in his garden. Furthermore, it encourages the young collector to want to know more about the way in which the scientific classification of species is organized. All the technical terms used are explained in a glossary, and there is a separate check list of all the species as well as an index of English names. The last section contains nearly four hundred miniature maps indicating the localities in Europe where each species may be found.

The introduction, which contains general hints on collecting, might be thought rather old-fashioned by some experts, but, if so, it is to be looked on as a touch of old-world charm which serves to indicate the immense pleasure which two authors of riper years have derived from a lifetime spent in the study of butterflies. A spccial feature of this book is the excellence of the illustrations. Every species and many of the subspecies have a coloured illustration of both upper and underside, and of both sexes. So often in natural history books one sees illustrations in which the artist has painted not so much what he actually sees as what he thinks he ought to see and the result is often disappointing. In the young and talented artist Brian Hargreaves, the authors have an illustrator who attains the highest standard of butterfly pictures I have seen. Fellow worshippers of these glorious insects will pray that he may be persuaded to devote his life's work to painting the butterflies of the whole world. Such a work would indeed be a major contribution to natural history.

In the text, each species receives about half a page into which are tucked a description which notes all special distinguishing features, the distribution and range, cater. pillar food plants and the type of country where it is most likely to bo found. Similar species which are most likely to be corifused aro also noted.

Even for those with only a passing interest, this book is a "must".

E. R. Laithwaite

\section{BREATHING REFLEXES}

\section{Breathing}

Hering-Breuer Centenary Symposium. Edited by Ruth Porter. (A Ciba Foundation Symposium.) Pp. xiv +402 . (Churchill: London, 1970.) $80 s$.

IN April 1868, Hering described, with full acknowledg. ment, work performed by his pupil Breuer entitled "Selfsteering of Respiration through the Nervus vagus". Later that year, Breuer published the full account of his work on the reflex effects upon breathing which occur when the lungs of certain animals are inflated and deflated. The inhibition of breathing which follows inflation of the lungs has since become known as the "Hering-Breuer reflex". This was the first convincing demonstration in biology and perhaps in any discipline of what today would be called "feedback". It made a great impression on physiology and medicine and disturbance of this reflex was later to be invoked to explain a wide variety of respiratory disturb. ance in disease. It is only in the past decade, however, that the reflex has been studied directly in man and its significance and limitations in discaso clarified. New reflexes arising from different receptors within the lungs have also been identified and their possible role in disease in place of the Hering-Breuer reflex considered. 